\title{
THREATENED FISHES OF THE WORLD: Telestes croaticus (Steindachner, 1866) (Cypriniformes: Cyprinidae)
}

\author{
Dušan Jelićc $^{1 *}$, Gabriella Krivek ${ }^{2}$
}

${ }^{1}$ Croatian Institute for Biodiversity, Lipovac I, no. 7, 10000 Zagreb, Croatia

2University of Szeged, Department of Ecology, Közép fasor 52, 6726 Szeged, Hungary

*Corresponding Author, Email: jelic.dusan@gmail.com

\section{ARTICLE INFO}

Received: 1 February 2016

Received in revised form: 10 January 2017

Accepted: 20 January 2017

Available online: 7 February 2017

\begin{abstract}
Telestes croaticus is a freshwater fish endemic in Croatia. It is a stygophile species, living above ground but occasionally retreating into subterranean waters. This species is found in the southwest region of Croatia, in the LikaJadova and Ričica drainages, in cold and clear waters in lowland habitats with little current, and in springs and associated wetlands. It is protected under Croatian law and was listed by the IUCN Red List as Endangered (EN). It has an extremely limited distribution which makes it vulnerable to different kind of traits such as habitat destruction, water extraction, dam construction, agricultural water pollution and especially the introduction of non-indigenous fish species. Suggested conservation actions for this species are: bans on watercourse regulation, reduction of pollution and eradication of alien fish species. Due to its fast decline in the last 10 years, it is our proposition that $T$. croaticus should be upgraded to a Critically Endangered species under criterion A2ace A4ace.
\end{abstract}

\section{Keywords:}

Telestes croaticus

Cyprinidae

Stygophile

Critically endangered

Croatian endemic fish
Jelic, D., Krivek, G. (2017): Threatened fishes of the world: Telestes croaticus (Steindachner, 1866) (Cypriniformes: Cyprinidae). Croatian Journal of Fisheries, 75, 25-29. DOI: 10.1515/cjf-2017-0005.

\section{SYNONYMS}

None

\section{COMMON NAMES}

Hrvatski pijor (Croatian)

Croatian minnow (English) (Fig. 1)

\section{TAXONIMIC NOTES}

None

\section{GEOGRAPHIC RANGE INFORMATION}

Telestes croaticus is endemic in Croatia. It occurs in endorheic rivers in the Dalmatian karst, in the Jadova, Novčica, Ričica, Otuča and in Gacko polje (Crivelli, 2006). In the early twentieth century, the species was present in large parts of the endorheic Lika drainage basin (in the Jadova, Novčica, Lika, Otešica; Langhoffer, 1904; Trgovčević, 1905, 1908, 1932). Apart from the Lika River drainage, it was found in the Ljubica stream near Baške Oštarije (Poljak, 1924) and in several streams of the Ričica basin around the town of Gospič: Ričica, Krivak, Suvaja, Banica, Otuča and Opsenica (Habeković et al., 1992). Brusina (1892) and Franić (1900) 


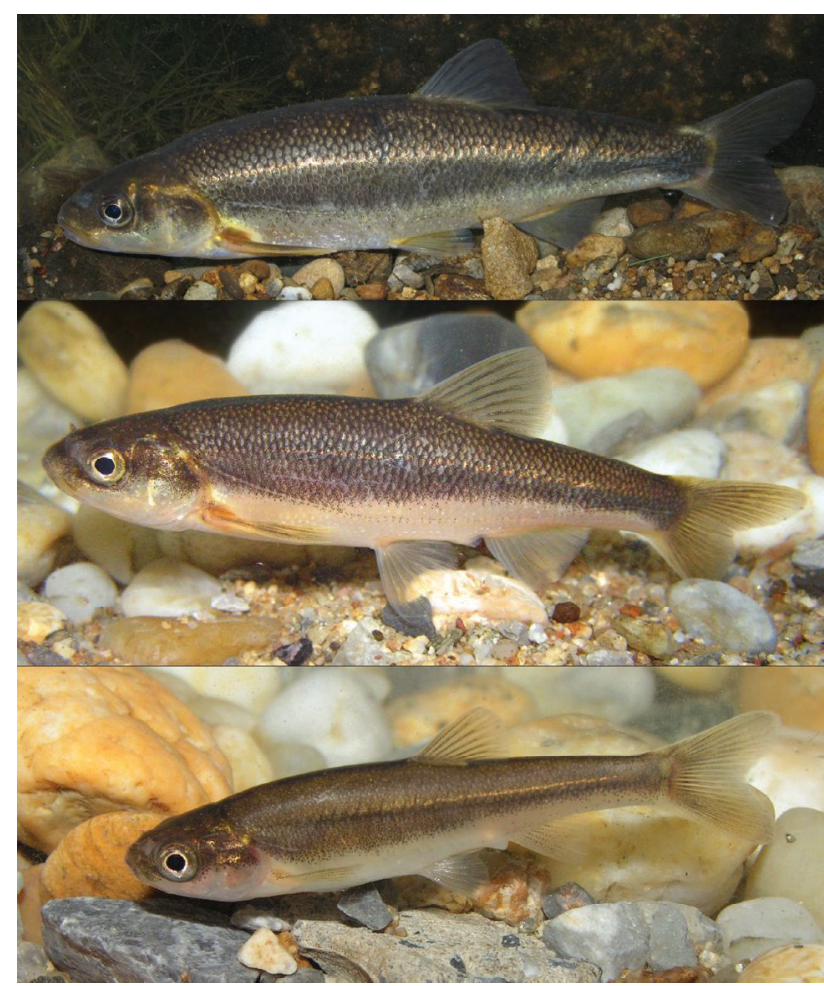

Fig 1. Telestes croaticus from the Ričica River: a) adult individual, total length $(\mathrm{TL})=165 \mathrm{~mm}$; b) young adult, $\mathrm{TL}=110 \mathrm{~mm}$; ) juvenile individual, $\mathrm{TL}=46$ $\mathrm{mm}$ (photo by Dušan Jelić)

mentioned an unknown minnow species (pijor) from the Gacka River system (Konjsko polje, Kompolje), which was later argued to belong to T. croaticus by Jelic et al. (2016) due to the connection of the Gacka and Lika Rivers.

The estimated area of occupancy (AOO) of the actual range is $16 \mathrm{~km}^{2}$ divided into two distinct conservation units (Jadova, $4 \mathrm{~km}^{2}$ and Ričica/Opsenica, $12 \mathrm{~km}^{2}$ ). The estimated actual extent of occurrence (EOO) is $84 \mathrm{~km}^{2}$ ( $\sim 2 \mathrm{~km}$ river length) out of the total of $628 \mathrm{~km}^{2}$ ( $314 \mathrm{~km}$ river length) of available areas with mostly unfavourable habitats. Both values were calculated as river length for exact localities where species was recently recorded based on IUCN Guidelines 3.1. (IUCN, 2012). Table 1 summarises historical and current range based on the size of polygons indicated in Figure 2.

\section{POPULATIONS}

Recent data indicate that $T$. croaticus disappeared from the Rivers Lika, Novčica, Balatin, Otuča, large part of the Ričica (lower parts) and the Gacka, with a visible decline of population size in the Ričica River over the last 10 years (Jelić et al., 2016). Nowadays it is present only in the Lika-Jadova and Ričica drainages (Fig. 2) (Zupančič and Bogutskaya, 2002; Ćaleta et al., 2015; Jelić et al., 2016).
Table 1. Summary of range (EOO) changes for Telestes croaticus from historical times to 2006 and until 2016 (last 10 years)

\begin{tabular}{lccccc}
\hline & $\begin{array}{c}\text { Historical } \\
\text { range } \\
\left(\mathrm{km}^{2}\right)\end{array}$ & $\begin{array}{c}\sim 2006 \\
\left(\mathrm{~km}^{2}\right)\end{array}$ & $\begin{array}{c}\text { Reduction } \\
\text { till 2006 }\end{array}$ & $\begin{array}{c}\text { Current } \\
\text { range } \\
2016 \\
\left(\mathrm{~km}^{2}\right)\end{array}$ & $\begin{array}{c}\text { Reduction } \\
\text { in 10 } \\
\text { years }\end{array}$ \\
\hline Gacka & 30 & 0 & $100 \%$ & 0 & $0 \%$ \\
Lika - Jadova & 1300 & 120 & $91 \%$ & 20 & $83 \%$ \\
Ričica & 400 & 135 & $66 \%$ & 22 & $84 \%$ \\
SUM & $\mathbf{1 7 3 0}$ & $\mathbf{2 5 5}$ & $\mathbf{8 5 \%}$ & $\mathbf{4 2}$ & $\mathbf{8 4 \%}$ \\
\hline
\end{tabular}

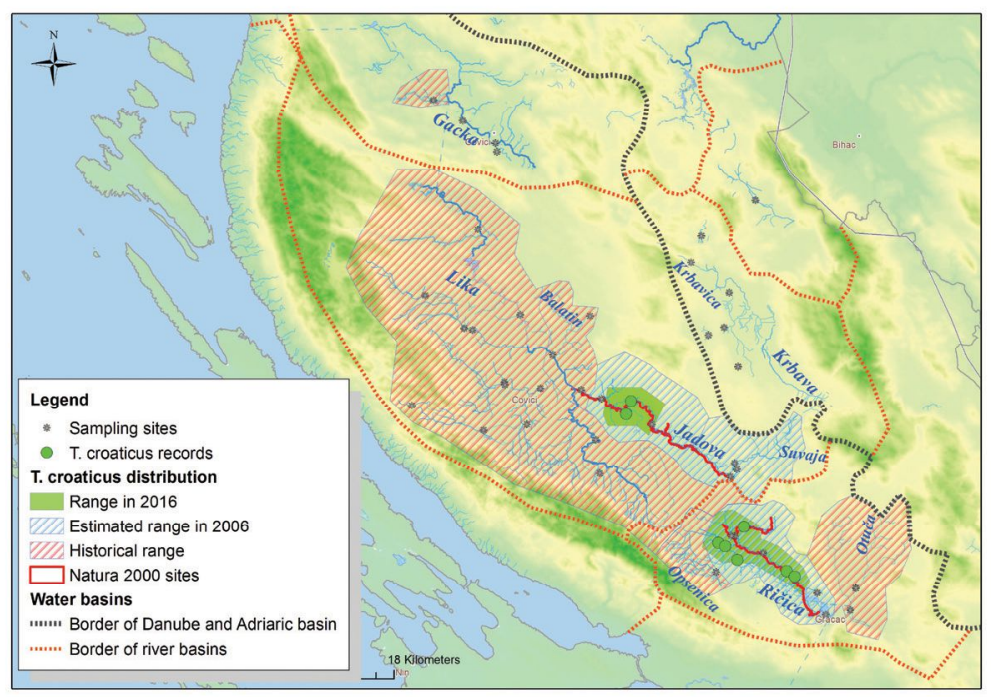

Fig 2. Historical and current range of Telestes croaticus. Data summarized by Jelić et al. (2016). Natura 2000 sites - the Jadova (HR2001272) and Ričica (HR2001267) - marked in red

These two basins are not connected and the species form two independent populations and conservation units. Both populations are fast declining. Table 1 summarises historical and current range based on the size of polygons indicated in Figure 2. It indicates ca $85 \%$ of total range reduction in the last $\sim 100$ years and from the remaining range another $84 \%$ reduction in the last 10 years. Over the last 10 years, EOO has significantly decreased both in the Ričica River area $(83 \%)$ and in the Jadova River area $(84 \%)$. There is a continuing decline in EOO due to the loss of subpopulations, in AOO due to human induced drought in some localities, in quality of habitat due to pollution and number of mature individuals due to invasive species (Crivelli, 2006).

It was found in the early phase of the impoundments of Ričica Dam Lake, which is used as storage for water for the Zrmanja hydropower plant. While Telestes croaticus was able to survive under lacustrine conditions for several years, it has now vanished from the impoundment due to 
strong invasion of alien species (Jelić et al, 2016). As native and alien species were introduced from the Zrmanja to the Ričica, this species recently became almost extirpated in the Ričica (Freyhof, 2012).

\section{HABITAT AND ECOLOGY}

Telestes croaticus inhabits cold and clear lowland streams with little current, karstic springs and associated wetlands in karst regions (Mrakovčić et al., 2006). It is able to colonize stagnant water bodies but is suspected to depend on flowing waters of spring steams for spawning. Telestes croaticus might enter subterranean habitats during the winter or dry periods (Kottelat and Freyhof, 2007), or dig itself into the stream substrate (Mrakovčić et al., 2006). Telestes croaticus is considered to be a stygophile species, living principally above ground and occasionally retreating into caves during long periods of drought in order to survive. It shares this adaptation to subterranean life with some other species of freshwater fish in Dinaric Arc (Telestes fontinalis, Delminichthys spp. and Phoxinellus spp.), which makes them unique on the European continent (Jelić et al., 2016). This adaptation is not a characteristic of other fish (specially introduced species) as they usually die within a short period of life in the subterranean waters due to lack of orientation and food location in total darkness.

\section{BIOLOGY}

Spawning season occurs between March and May in shallow current waters. Females aggregate during spawning and lay their eggs on a rocky or pebbled surface (Mrakovčić et al., 2006). Size at first sexual maturity of females is about $66 \mathrm{~mm}$ $\mathrm{SL}$ and of males is $52 \mathrm{~mm} \mathrm{SL}$ (Kottelat and Freyhof, 2007). Males have nuptial tubercles (small conical thickenings of the epidermis) during spawning (Ćaleta et al., 2015). It feeds on insect larvae, crustaceans, invertebrates and dead organic matter (Markotić et al., 2013). The generation length of this species is around $3.5-4.0$ years.

\section{THREATS}

Populations are threatened due to habitat destruction which is caused by water pollution from intensive agriculture ('́aleta et al., 2015). Due to construction of reservoirs and water extraction, several parts of the Jadova River drainage dry up during dry period (from June to September), thus isolating the (most) upper parts inhabited by the native ichthyofauna from the lower parts which are mostly populated by introduced species (Jelić et al., 2016). Endemic species are retreating into areas mostly inaccessible to introduced species, like the upper parts of the Jadova and Ričica, or they retreat into grabe (local denomination for deeper ponds that retain water even during dry season, usually continuing into underground cave system). But people are actively dispersing invasive fish over these natural barriers and they manage to establish their populations in these permanent ponds. Endemic fish resistance to the impacts of dam constructions (such as habitat alterations, alien species invasion) is considered very low (Freyhof, 2012). Telestes croaticus is very sensitive to introduction of alien species such as Alburnus arborella, Squalius cephalus and Lepomis gibbosus (Kottelat and Freyhof, 2007). Jelić et al. (2016) investigated one such graba in Vrebac, the middle Jadova, between 2006 and 2013, and reported a very rare occurrence of Carassius auratus, S. cephalus and Tinca tinca. DJ visited this locality again in 2016 and introduced species already comprised ca $65 \%$ of total biomass (Dušan Jelic pers. comm.). This indicates negative future trend for the native species, $T$. croaticus, Delminichthys jadovensis and Cobitis jadovaensis. Furthermore, Phoxinus ketmaieri, introduced from the Zrmanja, is now the most frequent species in the Ričica River and, as a competitor, probably the biggest threat to the endemic $T$. croaticus. These two small-bodied species might have almost identical ecological niches and it is evident that $P$. ketmaieri dominates the habitats where previously only $T$. croaticus was present (Jelič et al., 2016).

\section{USE AND TRADE}

\section{None}

\section{CONSERVATION ACTIONS}

In Croatia, as it is considered nationally endangered (EN; Mrakovčić et al., 2006), it is protected by the Nature Protection Act. It is also included into Natura 2000 ecological network and two sites were designated for this species: the Jadova (HR2001272) and Ričica (HR2001267). While site protection helps to preserve the species, it is not effective in preventing the invasion of alien species which actually pose the biggest threat to $T$. croaticus.

\section{CONSERVATION RECOMMENDATIONS}

Habitat protection, bans on further regulation and alteration of watercourse, reduction of pollution, restriction of introduction and control of alien fish species are recommended. A National Management Plan with action plan should be developed for this species and its habitat. Site protection clearly fails to save $T$. croaticus and several other endemic species from extinction. Alien species invade protected sites and the possibilities for the elimination of alien species should be seriously considered. Research on how to implement this shall immediately start. 


\section{RATIONAL FOR THE RED LIST ASSESSMENT}

Telestes croaticus is divided into two, historically three, isolated populations (the Gacka, Lika and Ričica Rivers). The major threat to the survival of this species, in both remaining populations, is invasive species. The species was already assessed as Endangered based mostly on an unknown decline and two remaining populations (EN B1ab(i,ii,iii,iv,v )+2ab(i,ii,iii,iv,v) (Crivelli, 2006).

Our analysis of the historic range and the recent declines strongly suggests that the total historic range was reduced by $85 \%$ until 2006 , and in the last 10 years by another $84 \%$ (compared to 2006) (Table 1). Jelić et al. (2016) also express visible decline of both subpopulations during the last 10 years, but due to lack of research there is no quantitative data available. T. croaticus should be upgraded to Critically Endangered due to the observed geographic decline by at least $84 \%$ over a 10 -year period (2006 - 2016) and consequential population decline with projections that the decline would continue over the next 10 years (20162026) where the reduction and its causes have not ceased and are not reversible, and can also be projected into the future - A2ace A4ace (estimated in IUCN ver. 3.1). Bearing in mind the lack of any efficient action for stopping or reversing the decline in near future, we fear the species faces serious risk of extinction. Concerning the $\mathrm{EOO}$ and $\mathrm{AOO}$, the species does not meet the criterion B1b(i,ii,iii,iv,v) and B2b(i,ii,iii,iv,v) to qualify as Critically Endangered as the population is not considered to be severely fragmented, i.e. number of locations is $=1$ and there are no extreme fluctuations of any of the parameters (i,ii,iii,iv,v). The division into two distinct isolated populations, which ought to be treated as separate conservation units, should also be taken into further consideration (Jelić et al., 2016).

\section{SAŽETAK}

\section{UGROŽENE VRSTE RIBA U SVIJETU: Telestes croaticus (Steindachner, 1866) (Cypriniformes: Cyprinidae)}

Hrvatski pijor, Telestes croaticus, je slatkovodna vrsta ribe endemična za slijev rijeke Jadove i Ričice. Smatra se da je prava stigofilna vrsta, po čemu je jedinstvena u Europi. Karakterizira je da jedan dio života provodi u podzemnoj vodi, ali živi u rijekama i potocima. Zakonom je zaštičen u Hrvatskoj, a nalazi se i na Crvenom popisu kao ugrožena vrsta (EN). Glavni uzroci ugroženosti ove vrste su ograničeno područje rasprostranjenosti, isušivanje i pretjerano iskorištavanje krških vodotoka, zagađenja i unos stranih vrsta riba. Predložene mjere zaštite za ovu vrstu su smanjenje zagađenja, kontrola regulacije vodotoka i uklanjanje stranih vrsta. Za ovu vrstu potrebno je napraviti ponovnu procjenu IUCN statusa i unaprijediti ju u kritično ugroženu vrstu (CR) na temelju kriterija A2ace A4ace.

Ključne riječi: Telestes croaticus, Cyprinidae, stigofil, ugrožene vrste, hrvatska endemska vrsta

\section{REFERENCES}

Brusina, S. (1892): Pabirci za hrvatsku ihtiologiju i za ribarstvo. Glas. Hrv. Naravos. Druš. VII: 1-68.

Ćaleta, M., Buj, I., Mrakovčić, M., Mustafić, P., Zanella, D., Marčić, Z., Duplić, A., Mihinjač, T., Katavić, I. (2015): Hrvatske endemske ribe, Agencija za zaštitu okolišta, Zagreb, pp: 100-104.

Crivelli, A. J. (2006): Telestes croaticus. The IUCN Red List of Threatened Species. Version 2015.2. <www.iucnredlist. org> Downloaded on 24 June 2015.

Franić, D. (1900): Zemljopisne iskrice iz jugo-zapadne Hrvatske. Glas. Hrv. Naravos. Druš. XII (1-3): 169-171.

Freyhof, J. (2012): Threatened freshwater fishes and molluscs of the Balkan, Potential impacts of hydropower projects, Berlin, ECA Watch Austria and EuroNatur, pp. 40.

Habekovič, D., Pažur, K., Popović, J. (1992): Ihtiofauna nekih ličkih tekućica. Ribarstvo, 47, 1-2, 23-33.

IUCN (2012): IUCN Red List Categories and Criteria: Version 3.1. Second edition. Gland, Switzerland and Cambridge, UK: IUCN. iv + pp. 32.

Jelič, D., Špelič, I., Žutinič, P. (2016): Introduced species community over-dominates endemic ichthyofauna of high Lika plateau (Central Croatia) over a 100 year period. Acta Zool Academ Sci Hung 62, 2, 191-216.

Kottelat, M., J. Freyhof, (2007): Handbook of European freshwater fishes. Publications Kottelat, Cornol and Freyhof, Berlin, pp. 646.

Langhoffer, A. (1904): Popis riba, koje su prispjele narodnom zoološkom muzeju u Zagrebu do konca godine 1900 . Glasnik Hrv. Naravosl. Dr. 16: 148-220.

Markotič, I., Mihaljevič, Z., Bartulovič, V., Dobroslavić, T., Šprem, S. J., Glamuzina, B. (2013): Sezonska ishrana prikanca (Phoxinellus pseudalepidotus Bogutskaya \& Zupančič, 2003) na području Mostarskog blata (Bosna i Hercegovina), pp. 654.

Mrakovčić, M., Brigić, A., Buj, I., Ćaleta, M., Mustafić, P., Zanella, D. (2006): Red book of freshwater fish of Croatia. Min. culture, SINP, Zagreb, pp. 253.

Poljak, J. (1924): Velebit (Fauna Velebita). Priroda XIV: 159176.

Trgovčevič, L. (1905): Paraphoxinus Blkr. i Telestes Bonap. u vodama Like i Krbave. Nastavni vjesnik, Zagreb, XIV.

Trgovčević, L. (1932): Lički piori Paraphoxinus Blkr., Telestes Bonap., Phoxinus Agass. In: Taler, Z. (ed.): Vode i ribe 
Jugoslavije. Zagreb, pp. 73-74.

Trgovčević, L., (1908): Prilog intiofauni ličkih potoka. Glas. Hrv. Naravos. Društva, 20: 229-239.

Zupančić, P., Bogutskaya, N. G. (2002): Description of two new species, Phoxinellus krbavensis and $P$. jadovensis, re-description of $P$. fontinalis Karaman, 1972, and a discussion of the distribution of Phoxinellus species (Teleostei: Cyprinidae) in Croatia and Bosnia-Herzegovina. Natura Croatica, 11, 4, 411-437. 